\title{
Significance of Atypical Pathogens among Community-Acquired Pneumonia Adult Patients Admitted to Hospital in Kuwait
}

\author{
N. Behbehani ${ }^{\mathrm{a}} \quad$ A. Mahmood ${ }^{\mathrm{a}}$ E.M. Mokaddas ${ }^{\mathrm{b}}$ Z. Bittar ${ }^{\mathrm{c}} \quad$ B. Jayakrishnan ${ }^{\mathrm{e}}$ \\ M. Khadadah ${ }^{a}$ A.S. Pacsa ${ }^{b}$ R. Dhar ${ }^{d}$ T.D. Chugh \\ Departments of a Medicine and ${ }^{\mathrm{b}}$ Microbiology, Kuwait University, Departments of ${ }^{\mathrm{c}}$ Medicine and ${ }^{\mathrm{d}}$ Microbiology, \\ Adan Hospital, and ${ }^{\mathrm{e}}$ Respiratory Unit, Chest Diseases Hospital, Kuwait
}

\section{Key Words}

Pneumonia, severity · Etiology

\begin{abstract}
Objectives: The aim of this study is to determine the microbial etiology and severity of community-acquired pneumonia (CAP) in Kuwait. Subjects and Methods: The severity of consecutive adult CAP cases admitted to 3 hospitals over a 1-year period was classified according to the Pneumonia Outcome Research Team (PORT) severity index. The microbial etiology was determined using standard methods for bacteria and serological tests for atypical and viral pathogens. Results: The study population was 124 of the 135 admissions; 63 female, 61 male; mean age $41.3 \pm 18$ years. The severity class distribution was: class $\mid 31 \%$, class || $37 \%$, class III $17 \%$, class IV $13 \%$, and class V $2 \%$. Etiological agents were identified from 44 patients $(35 \%)$, with one pathogen in 31 $(25 \%)$, two in $9(7 \%)$, and three or more in $4(3 \%)$. The most common pathogens identified were: Mycoplasma pneumoniae in 14 patients $(11 \%)$, Legionella pneumophila in $10(8 \%)$, Chlamydia pneumoniae in $8(6 \%)$, influenza B virus in $8(6 \%)$, influenza A virus in $5(4 \%)$, Haemophilus influenzae in $4(3 \%)$, Streptococcus pneu-
\end{abstract}

moniae in $3(2 \%)$, Staphylococcus aureus in $3(2 \%)$, gramnegative enterobacteria in $5(4 \%)$, Moraxella catarrhalis in $2(2 \%)$, and viruses in $4(3 \%)$. The yields from laboratory tests were $48 \%$ for paired serology, $20 \%$ from adequate sputum sample, and $3 \%$ from blood culture. Conclusion: Our study shows that a large percentage of mild CAP cases are admitted to hospitals in Kuwait. Atypical pathogens have a significant role in the etiology of CAP. There is overtreatment of CAP with a combination treatment consisting mainly of third-generation chephalosporins and macrolides.

Copyright $(2005$ S. Karger AG, Basel

\section{Introduction}

There are several studies from Europe and North America that describe the microbial etiology of community-acquired pneumonia (CAP) [1-3]. Despite extensive diagnostic testing in these studies, the responsible pathogen was not identified in as many as $50 \%$ of patients. In a recent retrospective study, which was the first in Kuwait [4], we found that the microbial etiology of CAP in Kuwait was identified in only $14 \%$ of the patients. The retrospective nature of this study and the lack of routine

\section{KARGER}

Fax +4161306 1234 E-Mail karger@karger.ch www.karger.com
(C) 2005 S. Karger AG, Basel

1011-7571/05/0144-0235\$22.00/0

Accessible online at: www.karger.com/mpp
Dr. Nasser Behbehani

Department of Medicine

PO Box 24923

13110 Safat (Kuwait)

Tel. +965 531 9596, Fax +965 533 8907, E-Mail nasser_beh@hsc.edu.kw 
Table 1. Criteria for microbiological diagnosis

\begin{tabular}{|c|c|}
\hline Organism & Diagnostic criteria \\
\hline All bacteria & $\begin{array}{l}\text { isolation from blood processed in } \\
\text { Bactec system or from pleural } \\
\text { fluid, or bronchoscopic aspirates }\end{array}$ \\
\hline $\begin{array}{l}\text { S. pneumoniae, } \\
\text { H. influenzae, } \\
\text { M. catarrhalis }\end{array}$ & $\begin{array}{l}\text { isolation from sputum in signifi- } \\
\text { cant numbers by semiquantitative } \\
\text { culture }\end{array}$ \\
\hline $\begin{array}{l}\text { Infection with other } \\
\text { bacteria including gram- } \\
\text { negative enterobacteria and } \\
\text { S. aureus }\end{array}$ & $\begin{array}{l}\text { the predominant organism in } \\
\text { sputum on Gram stain in addition } \\
\text { to isolation from sputum in signif- } \\
\text { icant number by semiquantitative } \\
\text { culture }\end{array}$ \\
\hline $\begin{array}{l}\text { Atypical and viral } \\
\text { pathogens C. pneumoniae, } \\
\text { L. pneumophila, M. pneu- } \\
\text { moniae, influenza A and B, } \\
\text { parainfluenza, respiratory } \\
\text { syncytial virus and } \\
\text { adenoviruses }\end{array}$ & $\begin{array}{l}\text { presence of IgM antibody or a } \\
\text { change in the optical density read- } \\
\text { ing of the EIA which corresponds } \\
\text { to at least 4-fold rise in IgG using } \\
\text { EIA kits (Virion/Serion, } \\
\text { Würzburg, Germany) }\end{array}$ \\
\hline
\end{tabular}

serological testing for certain organisms such as mycoplasma, chlamydia, legionella and viruses have contributed to this very low figure.

Since initial antibiotic management of CAP is usually empirical, it should be based on a clear understanding of the most likely pathogens. International guidelines for the empirical initial treatment of CAP [5] rely on studies done mainly in the Western world; hence this current prospective study was undertaken to determine the microbial etiology of CAP in Kuwait, to describe the clinical characteristics of patients presenting to hospital with $\mathrm{CAP}$ and the treatment received, and to determine the outcome of patients with CAP.

\section{Subjects and Methods}

This was a prospective study conducted over a 1-year period (September 2000 to September 2001). All consecutive adult patients aged 15 and over admitted to three hospitals (Al-Adan, Mubarak Al-Kabeer and Chest Diseases Hospitals) with a suspicion of pneumonia were eligible for the study and were evaluated by one of the authors. CAP was defined according to the presence of an acute illness of $\leq 21$ days duration with:

(1) Features of lower respiratory tract infection, which include (a) two or more of: new or increasing cough, sputum production, shortness of breath, wheeze, chest pain, new focal or diffuse signs on chest examination; (b) one or more constitutional symptoms including fever, confusion, sweating, headache, aches and pains, sore throat or coryza.

(2) Chest radiograph abnormality consistent with pneumonia, which was neither preexisting nor proven subsequently to be due to other causes.

(3) Physician's decision to treat the patient with antibiotics [2].

Patients were excluded from the study if pneumonia was not the primary cause for hospital admission. Patients with tuberculosis and HIV infection were excluded, as were those who had been in hospital within the previous 10 days, were immunocompromised (received immunosuppressive agents during the 6-month period before admission or corticosteroid more than the equivalent of prednisone $10 \mathrm{mg}$ daily for at least 3 months prior to admission). Comorbid illness was defined as the presence of any of the following conditions for which the patients were under active medical supervision or was receiving treatment at the time of hospital admission: cancer, chronic lung disease, cardiac failure, cerebrovascular disease (including previous transient ischemic attacks), diabetes mellitus, chronic liver disease, or chronic renal disease. Hence of the 135 patients admitted to the three hospitals, 124 (63 female and 61 male) were included in the study.

\section{Clinical Evaluation}

After obtaining informed consent, a structured data sheet was used to collect the clinical and laboratory data. The severity of pneumonia on admission was determined using the Pneumonia Outcome Research Team (PORT) severity index [6]. All chest radiographs were reviewed by the principal investigator (N.B.) to confirm the radiological abnormality. The patients were followed up regularly in hospital and after discharge until their clinical and radiological features stabilized. The main outcomes were judged by admission to the intensive care unit (ICU) and 30-day mortality.

\section{Microbiological Procedures}

Specimens. Specimens included: (1) two sets of blood cultures prior to antibiotic administration; (2) sputum within $24 \mathrm{~h}$ of admission; (3) acute and convalescent serums 14 days after primary diagnosis.

Methods. Blood culture bottles were incubated in Bactec 9240 (Beckton Dickinson, Md., USA). Sputum examination included Gram stain, modified Gram stain for legionella, Ziehl-Neelson stain if Mycobacterium tuberculosis was suspected. The sputum sample was determined to be adequate if more than 25 polymorphonuclear cells and less than 10 epithelial cells per high power field were present. Sputum culture was done on blood, chocolate, MacConkey, and Sabouraud's agar media as well as bile salt cystein yeast extract media for legionella (Oxoid, UK). Identification of bacteria and fungi and antimicrobial susceptibility testing of all the isolates were performed using Vitek2 automated system (BioMérieux, France). Antimicrobial susceptibility testing of all Streptococcus pneumoniae isolates was confirmed by minimum inhibitory concentration method using E-test (AB Biodisk). Serum samples were collected and stored at $4^{\circ} \mathrm{C}$ for serological testing of $\mathrm{Myco}$ plasma pneumoniae, Chlamydia pneumoniae, Legionella pneumophila, influenza A and B, parainfluenza virus, respiratory syncytial virus and adenoviruses by using Enzyme Immuno Assay IgG and IgM (Virion/Serion, Würzburg, Germany). The diagnostic criteria used to define infection are explained in table 1 [2]. 
Table 2. Characteristic of the study population $(n=124)$

\begin{tabular}{|c|c|c|}
\hline & $\mathrm{n}$ & $\%$ \\
\hline \multicolumn{3}{|l|}{ Mean age, range } \\
\hline \multicolumn{3}{|l|}{ Age groups, years } \\
\hline $15-44$ & 70 & 56 \\
\hline $45-64$ & 36 & 29 \\
\hline $65+$ & 18 & 15 \\
\hline \multicolumn{3}{|l|}{ Gender } \\
\hline Males & 61 & 49 \\
\hline Females & 63 & 51 \\
\hline \multicolumn{3}{|l|}{ Severity class ${ }^{1}$} \\
\hline Class I & 38 & 31 \\
\hline Class II & 46 & 37 \\
\hline Class III & 21 & 17 \\
\hline Class IV & 16 & 13 \\
\hline Class V & 2 & 2 \\
\hline \multicolumn{3}{|l|}{ Smoking status } \\
\hline Current smokers & 31 & 25 \\
\hline Ex-smoker (>6 months) & 9 & 7 \\
\hline Never smokers & 84 & 68 \\
\hline \multicolumn{3}{|l|}{ Comorbid illnesses } \\
\hline None & 81 & 65 \\
\hline Chronic lung disease & 16 & 13 \\
\hline Diabetes mellitus & 26 & 21 \\
\hline Cardiac failure & 6 & 5 \\
\hline Cerebrovascular disease & 5 & 4 \\
\hline Renal insufficiency & 5 & 4 \\
\hline Antibiotic taken prior to hospital admission & 49 & 40 \\
\hline Amoxicillin or penicillin & 23 & \\
\hline Macrolide & 8 & \\
\hline Cephalosporins & 4 & \\
\hline Other & 14 & \\
\hline
\end{tabular}

${ }^{1}$ Data not available for 1 patient.

\section{Statistical Analysis}

Data were analyzed using SPSS version $11.0 ; \chi^{2}$ test was used to compare categorical variables. Multivariate analysis was performed by stepwise logistic regression; $p$ value $<0.05$ was considered significant.

\section{Results}

\section{Clinical Characteristics}

Of the 11 patients excluded from the study, 6 had tuberculosis, 3 were immunocompromised, and 2 had lung cancer. The remaining 124 patients constituted the study population (table 2). The distribution of patients according to the hospital that they were admitted to was: 78 patients in Adan Hospital (63\%), 31 in Mubarak Hospital $(25 \%)$ and 15 in chest diseases hospital (12\%). The distri-
Table 3. Number (\%) of all pathogens detected

\begin{tabular}{lccc}
\hline Pathogen & Total & Age, years & \\
\cline { 3 - 4 } & $(\mathrm{n}=124)$ & $\begin{array}{l}<45 \\
(\mathrm{n}=70)\end{array}$ & $\begin{array}{l}\geq 45 \\
(\mathrm{n}=54)\end{array}$ \\
\hline Atypical pathogens & $32(26)$ & $16(23)$ & $16(30)$ \\
M. pneumoniae & $14(11)$ & $9(13)$ & $5(9)$ \\
L. pneumophila & $10(8)$ & $4(6)$ & $6(11)$ \\
C. pneumoniae & $8(6)$ & $3(4)$ & $5(9)$ \\
Bacterial pathogens & $17(14)$ & $8(11)$ & $9(17)$ \\
S. pneumoniae & $3(2)$ & $2(3)$ & $1(2)$ \\
H. influenzae & $4(3)$ & $2(3)$ & $2(4)$ \\
S. aureus & $3(2)$ & $2(3)$ & $1(2)$ \\
M. catarrhalis & $2(2)$ & $1(1)$ & $1(2)$ \\
GNEB & $5(4)$ & $1(1)$ & $4(7)$ \\
Viral pathogens & $17(14)$ & $11(16)$ & $6(11)$ \\
Influenza virus A & $5(4)$ & $3(4)$ & $2(4)$ \\
Influenza virus B & $8(6)$ & $6(9)$ & $2(4)$ \\
Respiratory syncytial virus & $2(2)$ & $1(1)$ & $1(2)$ \\
Adenovirus & $1(0.8)$ & $0(0)$ & $1(2)$ \\
Parainfluenza virus & $1(0.8)$ & $1(0.8)$ & $0(0)$ \\
Pathogens not identified & $80(65)$ & $45(64)$ & $35(65)$ \\
\hline
\end{tabular}

GNEB = Gram-negative enterobacteria.

bution of the severity of pneumonia was: class I $31 \%$ of the patients; class II 37\%; class III 17\%; class IV 13\%, and class V $2 \%$.

\section{Specimen Collection}

Specimens obtained included sputum within $24 \mathrm{~h}$ of admission from $111(90 \%)$ patients (but sputum samples from only 76 patients, $61 \%$, were considered adequate), blood culture prior to antibiotics in hospital from 110 patients (89\%), acute serum from $118(95 \%)$ and convalescent serum from $88(72 \%)$.

\section{Microbial Etiology}

Microbial etiology was determined in $44(35 \%)$ patients: one pathogen in $31(25 \%)$, two in $9(7 \%)$, and three or more in $4(3 \%)$. Altogether, $32(26 \%)$ atypical, $16(13 \%)$ bacterial, and $16(13 \%)$ viral pathogens were detected (table 3). The yield from the different tests was: $3 \%$ from blood culture, $20 \%$ from adequate sputum examination, and $48 \%$ from paired serology.

\section{Atypical and Viral Pathogens}

Atypical pathogens were identified serologically in 32 $(26 \%)$ of the patients. There were some differences between young ( $\leq 45$ years) and older patients, with $M$. 
Table 4. The percentage of patients needing ICU admission according to the PORT score ${ }^{1}$

\begin{tabular}{lll}
\hline Severity class & Patients & Patients needing ICU \\
\hline I & 38 & none \\
II & 46 & $3(7 \%)$ \\
III & 21 & $3(14 \%)$ \\
IV & 16 & $7(43 \%)$ \\
V & 2 & $1(50 \%)$ \\
\hline
\end{tabular}

$p<0.001, \chi^{2}$ test for the difference between the groups.

${ }^{1}$ Data not available for 1 patient.

pneumoniae more common in young patients $9 / 70(13 \%)$ compared to older patients $5 / 54$ (9\%), while L. pneumophila and $C$. pneumoniae were more common in older patients at $6 / 54(11 \%)$ and $5 / 54(9 \%)$, respectively, compared to young patients at $4 / 70(6 \%)$ and $3 / 70(4 \%)$. However, these differences did not reach statistical significance. Viral pathogens were identified in $16(13 \%)$ patients. Influenza B virus was identified in $8(6 \%)$ patients, followed by influenza A virus in $5(4 \%)$, while respiratory syncytial virus was identified in $2(2 \%)$. There were no differences observed between young and older patients with regard to viral pathogens.

\section{Bacterial Pathogens}

There was no difference in the rate of identification of bacterial pathogens between the patients who received antibiotics prior to admission ( $8 / 49$ or $16 \%)$ and the patients who had no antibiotics prior to admission (10/75 or $13 \%)$. Three patients had pathogens identified from blood cultures, 2 S. pneumoniae and 1 Staphylococcus aureus. Haemophilus influenzae and Moraxella catarrhalis were identified from sputum culture in 4 and 2 patients, respectively. There were 5 patients who fulfilled the criteria for aerobic gram-negative enterobacterial infection, 2 with Pseudomonas aeruginosa, 2 Klebsiella pneumoniae, and 1 Acinetobacter spp.

\section{Mixed Infections}

Of the 17 patients who had bacterial infection, copathogens were identified in 5, L. pneumophila in 3, and C. pneumoniae in 2 . Where atypical pathogens were identified (32 patients), copathogens were detected in 8 patients, bacterial infection in 5 (H. influenzae $1, S$. pneumoniae 2, M. catarrhalis $1, K$. pneumoniae 1$)$, and viral infection in 3 , a combined adenovirus and respiratory syncytial virus in 1 , and influenza B virus in 2 . There were 2 patients who had mixed influenza A and B viral infection.

\section{Clinical Outcome}

The 30 -day mortality was only $2 \%$ (2 patients). Both of these patients were young, aged 20 and 25 years; however, they both had pneumonia severity class IV on admission, and 1 had gross obesity and kyphoscoliosis with chronic respiratory failure, while the other patient had a history of prior poliomyelitis infection but did not have a documented respiratory problem prior to the pneumonia. The patient who had gross obesity and kyphoscoliosis arrived at the hospital unconscious and died on the 3rd day after admission with shock and severe hypotension, and the 2 nd patient died on the 9th day of admission with adult respiratory distress syndrome and multiorgan failure. The microbial etiology of either patient was not identified. Both patients were admitted to the ICU on the 1st day of admission and were on mechanical ventilation. Fifteen other patients were admitted to the ICU, 12 of whom required mechanical ventilation.

The distribution of severity classes was significantly different between the patients who needed ICU admission versus the patients who did not $(\mathrm{p}<0.001)($ table 4$)$. In a multivariate analysis using multiple logistic regression, the following were not predictors of the need for ICU admission: age, gender, smoking status, presence of comorbid condition, and admission heart rate, systolic blood pressure, temperature or white blood cell count. The only independent factors associated with ICU admission were: respiratory rate $\geq 30 / \mathrm{min}(\mathrm{OR}, 95 \% \mathrm{CI}, 1.4$, 1.1-1.7) and more than one lobe abnormality of the chest radiograph (OR 9.3, 1.2-70.5).

\section{Treatment}

The initial antibiotic regimen consisted of a single drug for $28(23 \%)$ patients and a combination of more than 1 drug for $96(77 \%)$ patients. The initial drug regimens used in order of frequency were: a combination of third-generation cephalosporin and a macrolide in 66 patients (53\%); a combination of second-generation cephalosporin and a macrolide in $13(10 \%)$; third-generation cephalosporin alone $13(10 \%)$; second-generation cephalosporin alone $10(8 \%)$; a combination of cephalosporins, macrolide, and aminoglycoside 9 (7\%), and other regimens 13 $(10 \%)$. 


\section{Discussion}

Our study showed that a large percentage of patients $(68 \%)$ admitted to hospitals in Kuwait have relatively mild pneumonia PORT classes I and II. This is different from an original study conducted in the United States where this scoring system was derived and validated [6], in which $31 \%$ of the cases admitted to hospital belonged to severity classes I and II, while the rest of patients belonged to more severe classes III-V. However, it must be noted that the age of the patients has a major impact in the PORT severity score, and it is well known that the proportion of young people in Kuwait is much larger than in the United States. The percentage of people between the ages of 15 and 59 years in the Kuwait population was $53.2 \%$ in 1999 , while the percentage of people 65 years and above was only $4.2 \%$ [7].

The PORT severity index has been shown to predict the need for hospitalization and mortality, and the majority of patients in classes I and II can be treated as outpatients with few or no complications. Furthermore, this severity score was used successfully in intervention studies aimed at decreasing hospital admission rates for CAP $[8,9]$. However, in these studies, $31-43 \%$ of patients in the lowest risk classes were still hospitalized on the basis of the treating physicians' judgments that they were too unstable for home-based care. The decision to admit patients with pneumonia to hospital depends on other factors besides the severity of pneumonia, such as the ability to take oral medication, social and psychological status of the patients, as well as availability of good medical follow-up for the patients. However, we feel the fact that in our study $68 \%$ of the patients admitted to hospital belong to classes I and II calls for a revision of our existing admission criteria, and we recommend using a stepwise approach in stratifying risk of pneumonia and the need for hospital admission [10].

The overall rate of identification of the microbial etiology, $35 \%$, was much better than the rate of $14 \%$ obtained in our previous retrospective study [4] from 1993 to 1995, but it is still considered low. However, other published studies on the etiology of CAP fail to identify a microbial organism in $40-50 \%$ of ambulatory patients and in $20-70 \%$ of hospitalized patients [5]. A somewhat surprising finding in this study was that there were only 3 cases of proven $S$. pneumoniae, which is widely regarded as the most common organism causing CAP among adult patients admitted to hospital [11], as it was also the predominant organism found in the retrospective study [4]. There are several possible explanations for this finding.
The overall yield from obtained sputum examination, which is the most commonly used method to diagnose $S$. pneumoniae in our study, was only 14\%. Despite our efforts in teaching the nursing staff in the method of collecting sputum samples, out of 111 sputum sample collected, only 76 (68\%) were considered adequate by microscopic criteria. This and the fact that we did not perform other specialized tests for $S$. pneumoniae like urine antigen or serology have certainly contributed to the low rate of $S$. pneumoniae in our study. Furthermore the fact that $40 \%$ of our patients received antibiotics prior to admission to hospital may have contributed to the low detection of bacterial pathogens, but there was no difference in the rate of identification of bacterial pathogens between the patients who received prior antibiotics or not. It is worth noting that there was no drug resistance among the three isolates of $S$. pneumoniae found in our study, and in a previous study the prevalence of full penicillin resistance among $S$. pneumoniae isolates in Kuwait was only $1.6 \%[12]$.

Our study is the first study that documents the significance of atypical pathogens in CAP among adults in $\mathrm{Ku}$ wait. The combined prevalence of atypical and viral pathogens in other published series ranged from 8 to $63 \%$ [13], but the prevalence found in the present study (26\%) may underestimate the true prevalence of these pathogens, probably because paired serology was obtained for only 88 patients out of the 124 in the study and newer methods like polymerase chain reaction on either respiratory secretions [14] or serum were not used. We found that $13(10 \%)$ of the patients had mixed microbial etiology, which represents $30 \%$ of the patients for whom an etiological agent was found. The observation of mixed infection among CAP patients, especially the coinfection of atypical and bacterial pathogens, is accepted as a wellestablished fact [13]; in recently published studies, multiple pathogens were found in 37\% [15], 38\% [2], and 48\% [16] of all patients for whom an etiological agent was reached.

There is a significant change in the antibiotics used in our study compared to the ones used during the retrospective study [4]. In the retrospective study, $80 \%$ of the patients received a single antibiotic - either ampicillin or a macrolide - as initial empirical therapy, while in the current study $79 \%$ received a combination of two antibiotics as initial therapy. In the retrospective study the most common antibiotics used were macrolide (33\%), ampicillin (29\%), cephalosporin (24\%), and penicillin (8\%). In the current study the combination of either third-generation or second-generation cephalosporins with a macro- 
lide was the most commonly used initial antibiotic regimen. We feel that this is due to the increasing awareness of the contribution of atypical pathogens in CAP. The macrolide used for the majority of patients was erythromycin as it was the only macrolide included in the hospital's formulary, which explains why it was often combined with a $\beta$-lactam antibiotic even though newer macrolides and the new respiratory quinolones are recommended to be used as single agents for certain patients with CAP [5]. We feel that the increasing usage of broad-spectrum antibiotics like third-generation antibiotics as initial empiric therapy, used for $72 \%$ of the patients in the present study either alone or in combination therapy, is not really justified especially given the relatively milder cases of CAP that are admitted to hospitals in Kuwait, and is not supported by the results of our microbial etiology.

\section{Conclusion}

Our study shows that a large percentage of mild CAP cases are admitted to hospitals in Kuwait. Atypical pathogens have a significant role in the etiology of CAP. There is overtreatment of CAP with a combination treatment consisting mainly of third-generation cephalosporins and macrolides.

\section{Acknowledgment}

This study was supported by Kuwait University grant No. MM042. We would like to thank Dr. P. Sharma for his help in the statistical analysis.

\section{References}

- 1 Fang GD, Fine M, Orloff J, Arisumi D, Yu VL, Kapoor W, Grayston JT, Wang SP, Kohler R, Muder RR: New and emerging etiologies for community-acquired pneumonia with implications for therapy: A prospective multicenter study of 359 cases. Medicine (Baltimore) 1990; 69:307-316.

-2 Lim WS, Macfarlane JT, Boswell TC, Harrison TG, Rose D, Leinonen M, Saikku P: Study of community acquired pneumonia aetiology (SCAPA) in adults admitted to hospital: Implications for management guidelines. Thorax 2001;56:296-301.

3 Ruiz M, Ewig S, Marcos MA, Martinez JA, Arancibia F, Mensa J, Torres A: Etiology of community-acquired pneumonia: Impact of age, comorbidity, and severity. Am J Respir Crit Care Med 1999;160:397-405.

-4 Awadh Behbehani N, Bitat Z, Alenezi F, Almutairi S, Alazmi M, Alsayeq F: A three-year study of community-acquired pneumonia in Kuwait with emphasis on microbial etiology. Med Principles Pract 2000;9:214-219.

5 Niederman MS, Mandell LA, Anzueto A, Bass JB, Broughton WA, Campbell GD, Dean N, File T, Fine MJ, Gross PA, Martinez F, Marrie TJ, Plouffe JF, Ramirez J, Sarosi GA, Torres A, Wilson R, Yu VL: Guidelines for the management of adults with community-acquired pneumonia: Diagnosis, assessment of severity, antimicrobial therapy, and prevention. Am J Respir Crit Care Med 2001;163:1730-1754.
-6 Fine MJ, Auble TE, Yealy DM, Hanusa BH, Weissfeld LA, Singer DE, Coley CM, Marrie T, Kapoor WN: A prediction rule to identify low-risk patients with community-acquired pneumonia. N Engl J Med 1997;336:243250

7 State of Kuwait, Ministry of Planning: Vital Statistics Report. Kuwait, 2000.

8 Atlas SJ, Benzer TI, Borowsky LH, Chang Y, Burnham DC, Metlay JP, Halm EA, Singer DE: Safely increasing the proportion of patients with community-acquired pneumonia treated as outpatients: An interventional trial. Arch Intern Med 1998;158:1350-1356.

-9 Marrie TJ, Lau CY, Wheeler SL, Wong CJ, Vandervoort MK, Feagan BG: A controlled trial of a critical pathway for treatment of community-acquired pneumonia. CAPITAL Study Investigators. Community-Acquired Pneumonia Intervention Trial Assessing Levofloxacin. JAMA 2000;283:749-755.

10 Metlay JP, Fine MJ: Testing strategies in the initial management of patients with community-acquired pneumonia. Ann Intern Med 2003;138:109-118.
11 Bartlett JG, Mundy LM: Community-acquired pneumonia. N Engl J Med 1995;333:16181624.

12 Mokaddas EM, Wilson S, Sanyal SC: Prevalence of penicillin-resistant Streptococcus pneumoniae in Kuwait. J Chemother 2001;13: 154-160.

13 Lieberman D: Atypical pathogens in community-acquired pneumonia. Clin Chest Med 1999;20:489-497.

- 14 Qasem JA, Khan ZU, Shiji G, Mustafa AS: Polymerase chain reaction as a sensitive and rapid method for specific detection of $\mathrm{Myco}$ plasma pneumoniae in clinical samples. Microbiol Res 2002;157:77-82.

15 Ragnar Norrby S: Atypical pneumonia in the Nordic countries: Aetiology and clinical results of a trial comparing fleroxacin and doxycycline. Nordic Atypical Pneumonia Study Group. J Antimicrob Chemother 1997;39: 499-508.

16 Lieberman D, Schlaeffer F, Boldur I, Horowitz $\mathrm{S}$, Friedman MG, Leiononen M, Horovitz O, Manor E, Porath A: Multiple pathogens in adult patients admitted with community-acquired pneumonia: A one year prospective study of 346 consecutive patients. Thorax 1996;51:179-184. 